\title{
Cylindrocladium pteridis Leaf Spot of Apricot Tree in The State of Para, Brazil
}

\author{
Luiz S. Poltronieri', Acelino C. Alfenas ${ }^{2}$, Edival A. V. Zauza ${ }^{2}$, Dinaldo R. Trindade ${ }^{1}$ \& Marli C. \\ Poltronieri ${ }^{1}$
}

${ }^{1}$ Embrapa Amazônia Oriental, Tv. Dr. Enéas Pinheiro, s/no , CEP 66095-100, Belém, PA, e-mail: poltroni@cpatu.embrapa.br; ${ }^{2}$ Departamento de Fitopatologia, Universidade Federal de Viçosa, CEP 36571-000, Viçosa, MG

(Aceito para publicação em 09/04/2003)

Autor para correspondência: Luiz S. Poltronieri

\begin{tabular}{|c|c|}
\hline \multicolumn{2}{|c|}{ RESUMO } \\
\hline $\begin{array}{l}\text { Mancha foliar em abricó causada por Cylindrocladium pteridis } \\
\text { Uma severa doença causada por Cylindrocladium pteridis emabricó }\end{array}$ & $\begin{array}{l}\text { (Mammea americana) foi detectada pela primeira vez no estado do Pará, } \\
\text { Brasil. O fungo foi isolado em laboratório e sua patogenicidade confirmada }\end{array}$ \\
\hline
\end{tabular}

The apricot (Mammea americana L.) is a fruit-bearing tree growm throughtout the entire Amazon region, especially in the state of Para, hence the name abrico-of-Pará (Cavalcante. Frutas Comestíveis da Amazônia, 1996). The fruits are used in salads, and in the forms of liquor, jelly and compote, all which keep the taste and flavor for long periods of time. The bark latex and the seed powder of apricot are reported to have an insecticidal effect that efficiently control of ticks, other insects, and animal parasites. Its wood tannins are used in the leather industry (Coral. O Abricoteiro, uma opção de investimento para o Estado do Pará. Boletim Técnico, SAGRI, 1998). In April 2002, during a routine plant pathological inspection of orchards in Marituba, PA, a generalized attack of a leaf spot disease was observed. Small light brown leaf spots, surrounded by a dark brown halo eventually resulted in the blight of the entire leaf (Figure1 A) and defoliation of the trees.

Isolations were made from the lesions by cutting tissues fragments from the lesion margins, which after disinfections in $2 \%$ sodium hypochlorite for $1 \mathrm{~min}$ and washing in sterile water, were placed on $2 \%$ water agar. After a seven-day incubation at $26 \pm 2{ }^{\circ} \mathrm{C}$, the fungal growth showed morphometric characteristics of Cylindrocladium pteridis Wolf (telemorph Calonectrica pteridis Crous et al.). The conidiophores are penicillate, with clavate vesicle and the conidia are cylindrical, hyaline, uniseptate, $65-76 \times 4.6-5.5 \mu \mathrm{m}$ (mean $70 \times 4.9 \mu \mathrm{m}$ ) (Figure $1 \mathrm{~B})$. For the pathogenicity tests, a $5 \mathrm{~mm}$ mycelial disc was placed on healthy apricot seedling leaves, while the PDA discs without the fungus served as control. All seedlings were placed in a moist chamber for $72 \mathrm{~h}$. Symptoms similar to the natural infection appeared on the leaves five days after inoculation while the control seedlings remained healthy. The fungus was reisolated from the lesions. Cylindrocladium pteridis has been reported from Brazil causing lesions on aciculae of Pinus caribea Morelet var. hondurensis ( Senecl.) W.H.G. Barret \& Golfari (Hodges et al. Brasil Florestal 6:8. 1975), in Cocus nucifera L. (Silva \& Souza. Fitopatologia bras. 6:515. 1981;
Ponte \& Silveira Filho. Fitopatologia bras. 22:67. 1997; Trindade et al. Fitopatologia bras. 23:412. 1998), in Mauritia flexuosa L. (Silva. Fitopatologia bras. 21:523. 1996) and in Eucaliptus spp. (Ferreira et al. Fitopatologia bras. 17:226.1992). No previous report was found in the literature regarding the occurrence of C. pteridis and symptoms of the foliar lesions on apricot; thus this is the first record of the pathogen on apricot in Brazil.

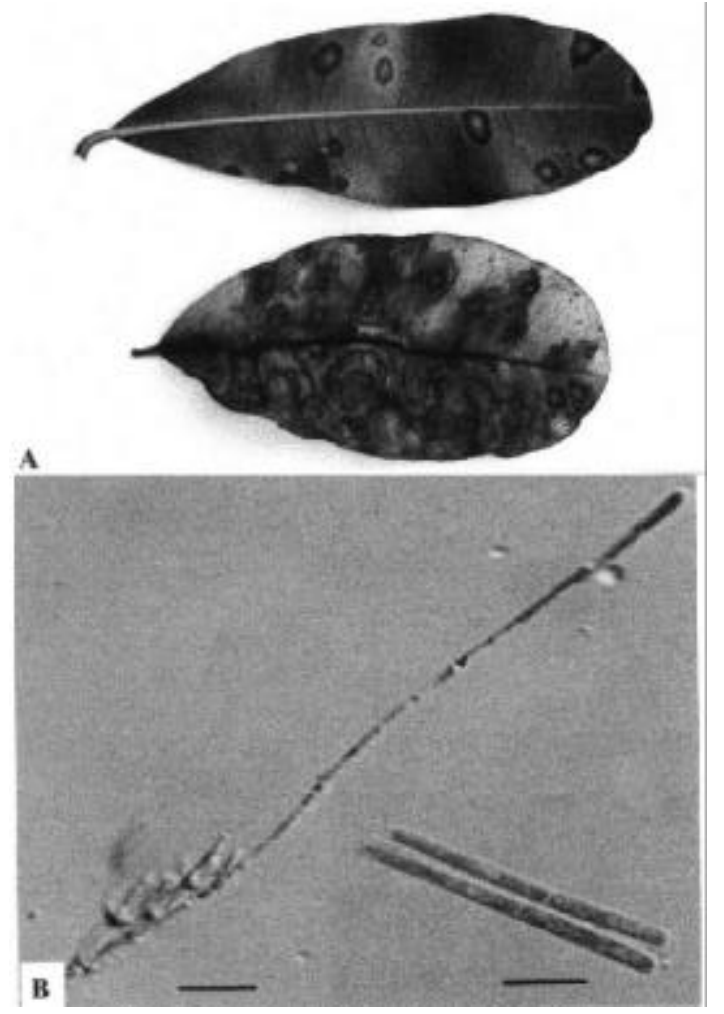

FIG. 1 - Cylindrocladium pteridis on abrico (Mammea americana): A- Leaf spot disease; B- Conidia, and conidiophores, and fungi vesicle. Bar $=20 \mu \mathrm{m}$. 